\title{
KNOWLEDGE MANAGEMENT AS A DRIVER OF COMPANY'S COMPETITIVE ADVANTAGE
}

\author{
Miloš Petković1*, \\ Lilian Del Real Ramirez ${ }^{2}$ \\ ${ }^{1}$ Singidunum University, \\ Belgrade, Serbia \\ ${ }^{2}$ IAE de Nice, Graduate School of \\ Management, \\ University Sophia Antipolis, \\ Nice, France
}

\begin{abstract}
:
In the last twenty years, global economy has changed radically. The industrial capitalism has transformed to capitalism based on knowledge. That change was revolutionarily in the current corporate world. In the core of knowledge-based economy are no longer tangible assets. Instead of them, intangible assets are now seen as its core. Information management presents the input, whereas knowledge management represents the final production output. In order to prevent these problems, there is the question of how knowledge is produced and used for some future economic value. The lack of identification of final outcomes coming from intangible assets may result with a huge loss of business opportunities.
\end{abstract}

Keywords:

knowledge management, competitive advantage, intellectual capital.

\section{INTRODUCTION}

In the economy based on knowledge, many corporations try to apply some of the knowledge management strategies mainly because knowledge is a core intangible resource (Skrzypek, 2004). Because of that, companies implement different processes of knowledge management that have a very significant role in the whole organization (Bitkowska, 2010; Drucker, 2003).

Knowledge management grew in the last 20 years as a tendency to create, acquire and communicate knowledge and improve its utilization because of the fact that individuals themselves cannot use the full potentials of their knowledge. At the same time, organizations cannot completely implement the knowledge they own as well, so organizations try to acquire and create new innovations that can be maximally used to increase organizational final result (King, 2009). Nowadays, companies must be innovative in the highly competitive global market. Considering all challenges that they face, it is of high importance to continuously capture competitive advantage. Hesitant customers, harsh competitors, advanced technology and new business models are all elements that create its business environment and force companies to remodel their operations (Nowacki and Bachnik, 2016).

Our paper is composed of six sections. The first two chapters are about knowledge and knowledge management. Further, it will be described how knowledge management and intellectual capital are interrelated, and how competitive advantage of a Correspondence: Miloš Petković company comes from knowledge management. The final sixth section concludes our study. 


\section{WHAT IS KNOWLEDGE?}

Knowledge can be very often defined as a personal belief (King, 2009). Traditional resources such as labor, land and financial capital surpasses completely the importance of knowledge. Knowledge can improve a company's competitive advantage (Nonaka, 2000; Quast, 2012; Wu and Wang, 2006). Knowledge is very important resource for all types of companies (Holsapple \& Joshi, 2000).

Literature proves that traditional financial indications of performance pay a little attention to the knowledge importance. These indications were under huge criticism in the last decades (Johnson and Kaplan, 1987; Kaplan, 1983; Thiel and Leeuw, 2002). Literature from management science has seen the role of knowledge in global competitiveness as very important. Knowledge is recognized as more sustainable and durable than any other resource within a company that will improve competitive advantage at the end (Barney, 1991; Drucker, P.F., 1988; Grant, 1991). Knowledge as a strategic resource improve organizational capabilities on the global market (Prahalad and Hamel, 1990).

\section{KNOWLEDGE MANAGEMENT DETERMINATION}

The process within a company that plans, organizes, motivates and controls people in order to ensure the improvement and effective use of knowledge assets is seen as knowledge management. All printed documents, such as patents, licenses, manuals, knowledge kept in electronic bases are knowledge-related assets. These assets are related to the best ways to do jobs, knowledge related to team work and knowledge stored in company products, processes and relationships (King, 2009).

Knowledge management is composed of several other management fields such as performance measurement, change management, human resources, information technology and valuation (Bueno, 2002; Bukowitz and Williams, 2000; Pablos, 2003). Intellectual capital is produced from knowledge management because intellectual capital is value created from knowledge (Bassi, 1997). The art of creating value from intangible assets of one company is defined as knowledge management (Sveiby, 1997). Success of a company cannot be imagined without knowledge management. If a company does not implement its own knowledge management system, it may miss all possible opportunities. The most important factor in any company's business is knowledge management (Krogh, 2009). Successful knowledge management brings better knowledge practices, improved organizational behaviors, better decisions and improved performance to a company (King, 2009). Knowledge management stimulates company's intellectual capital that brings further better employees' innovativeness and creativity (Van Beveren, 2002).
The process of knowledge collection and implementation to the specific key innovation goals of one company is defined as knowledge management (Krogh and Grand, 2000; Nonaka, 1994, 1991; 2003; Wiig, 1995, 1993; Wiig et al., 2000). The biggest challenge of a company is how to codify and transfer explicit and tact knowledge inside a company, among employees and departments (Lin, 2011). Koskinen (2004) maintains that differentiating between explicit and implicit knowledge inside a company is especially relevant and important. This study shows an important role of knowledge management because of a trust between company's employees and members.

\section{KNOWLEDGE MANAGEMENT AND ITS LINK WITH INTELLECTUAL CAPITAL}

Knowledge management is very strictly related with intellectual capital, and their relationship is very important for a company. The intellectual capital as a term cannot be seen as an accounting term, but it rather refers to 'capital' (Bukh et al., 2001). Boudreau and Ramstad (1997) associated intellectual capital with human resource management, while Davenport and Prusak (2010) linked intellectual capital to information technology. Intellectual capital is an invisible asset of a company and it is a value for the company (Hashim et al., 2015). Based on this definition, it can be concluded that management of knowledge generates or produces intellectual capital (Hashim et al., 2015). Knowledge management is a process inside a company, whereas intellectual capital covers all company's operations (Starovic and Marr, 2004).

Petty and Guthrie (2000) investigated the ways in which the information about intellectual capital supports and helps managers in the process of knowledge management application and implementation. Information about intellectual capital is closely related to the process of application, management, development and sharing of a company's knowledge (Drucker, 1993). Intellectual Capital Management (ICM) and Knowledge management (KM) are multidimensions and cover most of the fields in company's operations (Wiig, 1997). The relationship between knowledge management and intellectual capital management is to allow the present and future body of knowledge in order to secure long-term viability and profitability of a company (Wiig, 1997). 


\section{IMPROVING COMPETITIVE ADVANTAGE FROM SUCCESSFUL KNOWLEDGE MANAGEMENT}

Knowledge management's main role is to create and develop sustainable competitive advantage by integrating knowledge from a company's premium knowledge base.
This allows for customers' needs to be fulfilled by reaching higher loyalty, brand awareness and higher profits and market value (Sullivan, 1998). Intellectual capital can be used for benchmarking a company's knowledge base in order to produce greater revenues and market value (see Figure 28 below) (Srivastava, 2001):

Figure 1. Creation of Sustained Competitive Advantage (Stainfield, 1998)

\section{Knowledge Management}

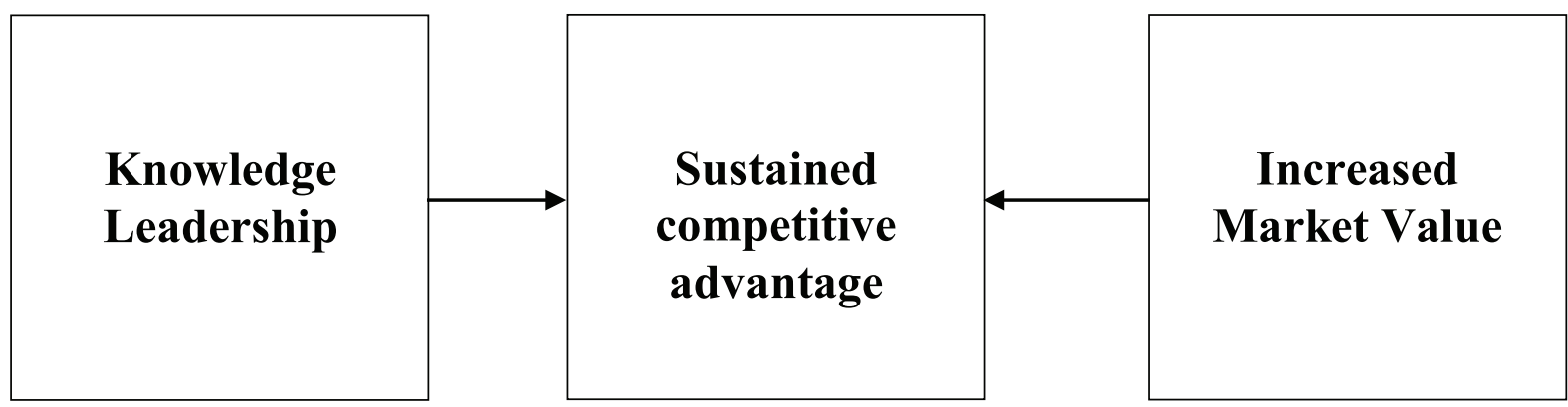

Premium Knowledge
Intellectual Capital

Benchmarking
The difference between knowledge management and intellectual capital can be described as the fact that knowledge management system manages intellectual capital seen as a company's knowledge. The knowledge owned by a company is intellectual capital. Knowledge management as a function describes and explains the act of managing an object, which is intellectual capital (Petty and Guthrie, 1999, 2000).

\section{CONCLUSION}

Utilization of advanced information technology and business management result in the rise of knowledge economy. Knowledge intensive companies have gained competitive advantage in knowledge economy. Intellectual capital is the main factor for enhancing not only corporate financial performance, but also a company's market value (Bozbura, 2004). So far, various researchers have added intellectual capital as a production factor, along with land, labor and financial capital (Goh, 2005). In knowledge economy, the financial performance of a company is always under first observation, not only by internal users of financial information, but by external users as well. The company's financial performance is under the direct or indirect influence of invisible assets and resources posed by a particular company. Those invisible assets or resources are called intellectual capital. Various empirical studies proved that intellectual capital itself directly influences financial company performance.

\section{LITERATURE}

Barney, J. (1991). Firm Resources and Sustained Competitive Advantage. Journal of Management, 17(1), 99-120. https://doi.org/10.1177/014920639101700108

Bassi, Laurie J. (1997). Harnessing the Power of Intellectual Capital. Training \& Development, 51(12), 25-30.

Bitkowska, A. (2010). Innovativeness in knowledge management. Innovation in Management and Entreprises Competiveness, 148-183.

Boudreau, J. W., \& Ramstad, P. M. (1997). Measuring Intellectual Capital: Learning from Financial History. 36(3), 343-356.

Brennan, N., \& Connell, B. (2000). Intellectual capital: Current issues and policy implications. Journal of IntellectualCapital, 1(3), 206-240. https://doi.org/10.1108/14691930010350792

Bueno, E. (2002). Direccio'n estrate' gica basada en conocimiento: Teori'a y pra'ctica de la nueva perspectiva. Nuevas Claves para la Direccio'n Estrate'gica.

Bukowitz, W. R., \& Williams, R. L. (2000). The knowledge management fieldbook (Rev. ed). Financial Times Management.

Danka Starovic, \& Marr, B. (2004). Understanding corporate value: Managing and reporting intellectual capital. Chartered Institute of Management Accountants (CIMA) and Cranfield University, London, 28. 
Davenport, T. H., \& Prusak, L. (2010). Working knowledge: How organizations manage what they know (Nachdr.). Harvard Business School Press.

Drucker, P. F. (1993). Post-capitalist society. HarperBusiness. http://books.google.com/books?id=dr2QAAAAIAAJ

Drucker, P. F. (2003). Innovation and entrepreneurship: Practice and principles (Reprint). HarperBusiness.

Drucker, P.F. (1988). The coming of the new organization. Harvard Business Review.

Goh, P.C. (2005). Intellectual capital performance of commercial banks in Malaysia. Journal of Intellectual Capital, 6(3), 385-396.

Grant, R. M. (1991). Contemporary strategy analysis: Concepts, techniques, applications (3. ed., repr). Blackwell Publishers.

Hashim, M. J., Osman, I., \& Alhabshi, S. M. (2015). Effect of Intellectual Capital on Organizational Performance. Procedia - Social and Behavioral Sciences, 211, 207-214. https://doi.org/10.1016/j.sbspro.2015.11.085

Holsapple, C. W., \& Joshi, K. D. (2000). An investigation of factors that influence the management of knowledge in organizations. The Journal of Strategic Information Systems, 9(2-3), 235-261. https://doi.org/10.1016/S09638687(00)00046-9

Johnson, T.H., \& Kaplan, R. S. (1987). Relevance Lost: The Rise and the Fall of Management Accounting. Harvard Business School.

Kailash B. L. Srivastava. (2001). Intellectual Capital Development and Management of Knowledge in Knowledge BasedEconomy. Indian Journal of Industrial Relations, 36(3), 355-362.

Kaplan, R. S. (1983). Measuring manufacturing performance: A new challenge for managerial accounting research. In C. Emmanuel, D. Otley, \& K. Merchant (Eds.), Readings in Accounting for Management Control (pp. 284-306). Springer US. https://doi.org/10.1007/978-1-4899-7138-8_14

King, W. R. (2009). Knowledge Management and Organizational Learning. In W. R. King (Ed.), Knowledge Management and Organizational Learning (Vol. 4, pp. 3-13). Springer US. https://doi.org/10.1007/978-1-4419-0011-1_1

Koskinen, K. U. (2004). Knowledge Management to Improve Project Communication and Implementation. Project Management Journal, 35(2), 13-19. https://doi. org/10.1177/875697280403500203

Krogh, G. von. (2009). Individualist and collectivist perspectives on knowledge in organizations: Implications for information systems research. The Journal of Strategic Information Systems, 18(3), 119-129. https://doi. org/10.1016/j.jsis.2009.08.001

Krogh, G. von, \& Grand, S. (2000). Justification in Knowledge Creation: Dominant Logic in Management Discourses. In Knowledge Creation (pp. 13-35). Palgrave Macmillan, London. https://doi.org/10.1007/978-1-349-62753-0_2
Lev, B., \& Daum, J. H. (2004). The dominance of intangible assets: Consequences for enterprise management and corporate reporting. Measuring Business Excellence, 8(1), 6-17. https://doi.org/10.1108/13683040410524694

Lin, H.-F. (2011). The effects of employee motivation, social interaction, and knowledge management strategy on KM implementation level. Knowledge Management Research \& Practice, 9(3), 263-275. https://doi. org/10.1057/kmrp.2011.21

Nonaka, I. (2000). A firm as a knowledge-creating entity: A new perspective on the theory of the firm. Industrial and Corporate Change, 9(1), 1-20. https://doi.org/10.1093/icc/9.1.1

Nonaka, Ikujirō. (1991). The knowledge-creating company. Harvard Business Review, 69(6), 96-104.

Nonaka, Ikujiro. (1994). A Dynamic Theory of Organizational Knowledge Creation. Organization Science, 5(1), 14-37. https://doi.org/10.1287/orsc.5.1.14

Nonaka, Ikujiro, \& Reinmoller, P. (2000). Dynamic business systems for knowledge creation and utilization. Despres, C. and Chauvel, D. (Eds), Knowledge Horizons: The Present and the Promise of Knowledge Management.

Nonaka, Ikujirō, \& Takeuchi, H. (1995). The knowledgecreating company: How Japanese companies create the dynamics of innovation. Oxford University Press.

Nowacki, R., \& Bachnik, K. (2016). Innovations within knowledge management. Journal of Business Research, 69(5), 1577-1581. https://doi.org/10.1016/j.jbusres.2015.10.020

Pablos, P. O. de. (2003). Knowledge management projects: State of the art in the Spanish manufacturing industry. International Journal of Manufacturing Technology and Management, 5(4), 297. https://doi.org/10.1504/ IJMTM.2003.003457

Petty, R., \& Guthrie, J. (1999). Managing intellectual capital from theory to practice. Australian CPA, 18-21.

Petty, R., \& Guthrie, J. (2000). Intellectual capital literature review: Measurement, reporting and management. Journal of Intellectual Capital, 1(2), 155-176. https:// doi.org/10.1108/14691930010348731

P.N. Bukh, H.T. Larsen, \& J. Mouritsen. (2001). Constructing intellectual capital statements. Scandinavian Journal of Management, 87-108.

Prahalad, C.K., \& Hamel, G. (1990). The core competence of the corporation. Harvard Business Review, 68(3), 79-91.

Quast, L. (2012). Why knowledge management is important to the success of your company. Forbes.

Skrzypek, E. (2004). Valuation of knowledge and intellectual capital, and their impact on the efficiency in the organization. Strategies of Information and Knowledge Management, 11-26.

Stainfield, K. (1998). How Knowledge Management and Intellectual Capital Relate. www.knowcorp.com

Sullivan H.P. (1998). Profiting from Intellectual Capital: Extracting Value from Innovation. John Wiley \& Sons. 
Sveiby, K. E. (1997). The new organizational wealth: Managing \& measuring knowledge-based assets (1st ed). BerrettKoehler Publishers.

Thiel, S. V., \& Leeuw, F. L. (2002). The Performance Paradox in the Public Sector. Public Performance \& Management Review, 25(3), 267. https://doi.org/10.2307/3381236

Tunc Bozbura, F. (2004). Measurement and application of intellectual capital in Turkey. The Learning Organization, 11(4/5), 357-367. https://doi.org/10.1108/09696470410538251

Van Beveren, J. (2002). A model of knowledge acquisition that refocuses knowledge management. Journal of Knowledge Management, 6(1), 18-22. https://doi. org/10.1108/13673270210417655

Wiig, K. M. (1993). Knowledge management foundations: Thinking about thinking: how people and organizations create, represent, and use knowledge. Schema Press.
Wiig, K. M. (1995). Knowledge management methods: Practical approaches to managing knowledge. Schema Press.

Wiig, K. M. (1997). Integrating intellectual capital and knowledge management. Long Range Planning, 30(3), 399-405. https://doi.org/10.1016/S0024-6301(97)90256-9

Wiig, K. M., Chauvel, E. D., \& Despres, C. (2000). Knowledge management: An emerging discipline rooted in a long history. Knowledge Horizons: The Present and the Promise of Knowledge Management.

Wu, J.-H., \& Wang, Y.-M. (2006). Measuring KMS success: A respecification of the DeLone and McLean's model. Information \& Management, 43(6), 728-739. https://doi. org/10.1016/j.im.2006.05.002 